\title{
Thermophilic Bacilli in Commercially Heat Treated Milks S.N.M.khalid ${ }^{1}$, E.M.A.Ibrahim ${ }^{2}$ H.A.mohammed ${ }^{2}$, N.A.shawky ${ }^{1}$. \\ ${ }^{1}$ Animal Health Research Institute "Shebin El Koom Branch", Egypt. \\ ${ }^{2}$ Food Control Dept., Faculty of Veterinary Medicine, Benha Univ., Egypt E-Mail:
}

\begin{abstract}
Thermophilic bacilli are an important group of contaminants in the dairy industry, as their presence in dairy products is an indicator of poor hygiene and high numbers are unacceptable to customers. A total of Fifty samples of pasteurized milk and UHT milk (25 of each) representing different brands available on the market were randomly collected in their retail containers from groceries, dairy shops and supermarkets in different localities at Menoufia governorate. These samples were examined bacteriologically for the presence of thermophilic aerobic spore forming bacilli. The highest incidence of thermophilic aerobic spore formers was in pasteurized milk followed by UHT milk with an incidence of $44 \%$ and $40 \%$ and with mean value of $1.3 \times 10^{4} \pm$ $8.6 \times 10^{3}$ and $9.4 \times 10^{2} \pm 3.9 \times 10^{2}$ C.F.U $/ \mathrm{ml}$, respectively. The most frequently isolated thermophilic $\left(55^{\circ} \mathrm{C}\right)$ strains in examined samples were Bacillus licheniformis followed by Bacillus stearothermophilus.
\end{abstract}

Keywords: Pasteurized milk, UHT milk, Thermophilic bacilli, Aerobic spore formers.

\section{Introduction}

Milk is known to be the most complete and valuable food in nature, as it contains fat, protein, sugar, minerals, vitamins and other various ingredients dispersed in it so, it is considered as complete diet [1].

Bacterial contamination of raw milk can be originated from different sources such as air, milking equipment, feed, soil, feces and water [2].

Spores of aerobic spore-forming bacteria are ubiquitous and can be isolated from a wide variety of sources in the dairy farm environment, including soil, silage, concentrate feeds, bedding and faeces. Contamination of raw milk by spores from these sources occurs during milking via contaminated udders and teats [3 and 4].

Among the Bacilli spores species isolated from dairy products are Bacillus cereus, Bacillus subtilis, Bacillus stearothermophilus, Bacillus licheniformis, Bacillus coagulans and Bacillus circulans, these are thermoresistant psychrotrophic aerobic or facultative anaerobic commonly isolated genera [5].

Bacilli species vary considerably with respect to the range of temperatures in which they can grow, and include some psychrophilic [6] and thermophilic species [7 and 8].

The facultative thermophiles belong to the Bacillus genus and tend to grow at both mesophilic and thermophilic temperatures, depending on the strain. Some examples of species include Bacillus licheniformis, Bacillus coagulans and Bacillus subtilis [9, 10 and 11].

Implementation of efficient pasteurization, sanitation and good quality milk has great effect to reduce the bacterial contamination in fluid milk, thus, contributing to the extension of milk's shelf life [12].

Heating temperature and the holding time are the main points to evaluate the effectiveness of a sterilization process regarding to destruction of pathogenic and spoilage microorganisms which responsible for restricting the shelf life and to quantify the chemical changes in heat treated milk [13].

Bacilli species represent a group of bacteria important for dairy industry due to the resistance of their spores and the ability of the vegetative cells to produce extracellular enzymes, which has proteolytic, lipolytic and saccharolytic activity; causing spoilage of the milk and milk products [14].

Heat-resistant proteolytic and lipolytic enzymes adversely affect the quality of dairy products during storage. Hence, flavor quality and textural problems are attributed to heat-stable protease activity [15].

Heat treatment may activate spore germination and the subsequent slow insufficient cooling or hot holding of food at temperatures too low may then allow germination out growth and multiplication, so there is still potential for food borne illness, additionally some of the species are food borne pathogens [16].

Relatively, little is known about the incidence of thermophilic aerobic spore forming bacteria in milk and milk products. Therefore, this study was conducted to throw out light on this group of bacteria with special reference to their incidence, counts and significance of isolated strains of such serious bacteria refereed to their public health hazard.

\section{Materials and methods}

\subsection{Collection of samples}

Fifty samples of pasteurized milk and UHT milk (25 of each) representing different brands available on the market were randomly collected in their retail containers from groceries, dairy shops and supermarkets in different localities at Menoufia governorate. All the samples were kept in an ice 
box till reach to the laboratory with minimum delay to be examined as rapidly as possible.

\subsection{Preparation of samples [17]}

The external surface of the package of pasteurized and UHT milk were thoroughly swabbed with $70 \%$ alcohol, and then thoroughly mixed by shaking and inverting before aseptically opened.

\subsubsection{Preparation of serial dilutions [17]}

$10 \mathrm{ml}$ of previously prepared milk samples were placed in sterile test tube, then heated in water bath at $80^{\circ} \mathrm{C}$ for 10 minutes (to kill vegetative cells except spore forming bacteria) then cooled from which tenth fold serial dilutions were prepared.The initial dilution was made by transferring $11 \mathrm{ml}$ of prepared samples (Pasteurized milk and UHT milk) immediately to $99 \mathrm{ml}$ of sterile saline solution adjusted at $45^{\circ} \mathrm{C}$ to make dilution of 1: 10 from which decimal dilutions were prepared.

\subsection{Enumeration of thermophilic aerobic spore formers [18]}

From the previously prepared serial dilutions, $0.1 \mathrm{ml}$ was seeded evenly onto the surface of duplicate sterile plates containing (dextrose tryptone agar medium) then incubated at $55^{\circ} \mathrm{c}$ for 48 hours for enumeration of thermophilic aerobic spore formers.

\subsection{Identification of suspected colonies}

Suspected colonies of aerobic spore formers were picked up and seeded into nutrient agar slopes then incubated at $37^{\circ} \mathrm{C}$ for 24 hours. The culture was morphologically and biochemically identified according to [19 and 20].

\section{Results and discussion}

\subsection{Results}

In table (1) the incidence of thermophilic aerobic spore formers in pasteurized milk and UHT milk samples were $44 \%$ and $40 \%$, respectively.

While the mean value of total thermophilic aerobic spore former counts in the examined samples of pasteurized milk and UHT milk were $1.3 \times 10^{4} \pm 8.6 \times 10^{3}$ and $9.4 \times 10^{2} \pm 3.9 \times 10^{2}$, respectively table (2).

Regarding the results in table (3), the most frequently isolated thermophilic strains from pasteurized milk samples were Bacillus licheniformis followed by Bacillus stearothermophilus with percentage of $28 \%$ and $20 \%$, respectively. While in UHT milk samples the most frequently isolated thermophilic strains were Bacillus licheniformis followed by Bacillus stearothermophilus with percentage of $24 \%$ and $20 \%$, respectively.

\subsection{Discussion}

Thermophilic spore forming Bacilli can survive pasteurization conditions and grow in pasteurized fluid milk during refrigerated storage [6 and 21] causing fluid milk spoilage and limiting the further extension of fluid milk's shelf life [22 and 23].

The results given in tables (1) and table (2) pointed out that the highest incidence of thermophilic aerobic spore formers was in pasteurized milk followed by UHT milk.

For pasteurized milk higher results than our obtained results were detected by [24] at incidence of $80 \%$ for examined pasteurized milk samples. While lower results than our obtained results were detected by [25] as they detected thermophilic spore formers in $27 \%$ of examined pasteurized market milk samples.

For UHT milk, the obtained results were lower than those recorded by Aly [24] were 52\% for examined UHT milk samples with mean value of $48.8 \pm 12.78$ C.F.U/ml. While obtained results were higher than results stated by [26] who found that $32 \%$ of examined UHT milk samples that stored at $55^{\circ} \mathrm{C}$ were contaminated with aerobic spores at count of $5.8 \times 10^{3}$ C.F.U $/ \mathrm{ml}$.

Tables (3) showed the incidence of isolated strains of thermophilic aerobic spore formers in examined heat treated milk samples (Pasteurized milk and UHT milk).

Our obtained results were agreed with those obtained by [27] as they detected that Bacillus licheniformis is the most frequently isolated strain from pasteurized milk samples.

Also obtained results agreed with those obtained by [28] as they could isolate Bacillus subtilis from pasteurized milk samples.

For UHT milk, our obtained results agreed with those obtained by [29] who reported that Bacillus licheniformis followed by Bacillus stearothermophilus were the most thermophilic spore formers commonly found in UHT milk samples.

[30] reported that Bacillus stearothermophilus is very heat resistant thermophilic strain that can cause flavor spoilage in UHT milk.

Bacillus subtilis has been associated with ropiness in raw and pasteurized milk as well as the spoilage of UHT milk [28]. While Bacillus coagulans have been connected to the spoilage of UHT milk due to the production of lactic acid [31].

Bacillus licheniformis are also capable of producing a slimy extracellular substance that can affect the quality of pasteurized milk [31].

Post-pasteurization contaminations of milk products are mainly due to the filling machines [32] and gaskets with biofilms [33].

The presence of some subtypes of spore formers exclusively in pasteurized samples throughout the milk chain, suggesting the possibility of in-plant sources for these spoilage organisms. The adhesive 
characteristic of some spore forming bacteria (i.e.

Bacillus stearothermophilus, Bacillus coagulans,

Bacillus cereus Bacillus licheniformis and Bacillus subtilis) might be contributing to their persistence in the processing environment [34 and 35].

Table (1) Incidence of thermophilic aerobic spore former in examined heat treated milk samples $\left({ }^{*} \mathrm{n}=25\right)$.

\begin{tabular}{lcc}
\hline \multirow{2}{*}{ Examined samples } & \multicolumn{2}{c}{ Positive samples } \\
\cline { 2 - 3 } & \multicolumn{2}{c}{ No. } \\
\hline Pasteurized Milk & 11 & 44 \\
UHT milk & 10 & 40 \\
\hline
\end{tabular}

Table (2) Statistical analytical results of total thermophilic aerobic spore formers count in examined heat treated milk samples $(* n=25)$.

\begin{tabular}{|c|c|c|c|c|}
\hline Examined samples & Min & Max & Mean \pm & S.E.M ${ }^{*}$ \\
\hline Pasteurized milk & $10^{2} \times 1.2$ & $10^{4} \times 9.8$ & $10^{4} \quad \pm \times 1.3$ & $10^{3} \times 8.6$ \\
\hline UHT Milk & $10^{2} \times 1.3$ & $10^{3} \times 3.9$ & $\pm \times 9.4$ & $10^{2} \times 3.9$ \\
\hline
\end{tabular}

Table (3) Incidence of isolated thermophilic aerobic spore former strains in examined heat treated milk samples $\left(*^{*}=25\right)$.

\begin{tabular}{lcccc}
\hline & \multicolumn{3}{c}{ Positive Samples } \\
\cline { 2 - 5 } Isolates & \multicolumn{3}{c}{ Pasteurized milk } & UHT milk \\
\cline { 2 - 5 } & No & \% & 6 & \% \\
\hline B. licheniformis & 7 & 28 & 4 & 24 \\
B. subtilis & 4 & 16 & 1 & 4 \\
B. macerans & 2 & 8 & 2 & 8 \\
B. brevis & 4 & 16 & 3 & 8 \\
B. polymxa & 3 & 12 & 5 & 20 \\
B. stearothermophilas & 5 & 20 & 1 & 4 \\
B. coagulans & 4 & 16 & & \\
\hline
\end{tabular}

\section{Conclusion}

Information given by the results obtained in this work pointed out the unsatisfactory conditions of pasteurized milk and UHT milk exposed for sale in Menoufia provinces, and this was due to lack of efficient supervision, processing, handling and storage of such products. The objectionable heavy contamination of these products with different types of thermophilic aerobic spore formers may result, into serious changes in the products rendering it of inferior quality or even unmarketable. Moreover, certain species of these organisms constitute a public health hazard among dairy products to consumers.

\section{References}

[1] A.Haug, A.T.Hostmark, and O.M. Harstad, Bovine milk in human nutrition- A review. Lipids Health DisVol. 6:25, doi: 10.1186/1476511X-6-25. 17894873,2007.

[2] S.Marjan, K.K.Das, S.K. Munshi, And R. Noor, Drug- resistant bacterial pathogens in milk and some milk products. Nutn. Food Vol .44 (3), pp241-24,2014.

[3] A.Eneroth, B.Svensson, G.Molin, and A.Christiansson,Contamination of pasteurized milk by Bacillus cereus in the filling machine. J. Dairy Research Vol.68, pp.189-196,2001.

[4] M.Simões, L.C. Simões, and M.J Vieira, A review of current and emergent biofilm control strategies. Food Sci and Technol. 43: 573-583,2010.

[5] Samarzija, D.; Zamberlin,S. and Pogacic. T. (2012): Pschrotrophic bacteria and milk and dairy products quality. Mijekarstro 62 (2):7795.

[6] R. A. Ivy, M. L. Ranieri, N. H .Martin , H. C. den Bakker, B. M. Xavier, M.Wiedmann, and K. J. Boor, Identification and characterization of psychrotolerant sporeformers associated with fluid milk production and processing. Appl. Environ. Microbiol. Vol.78:18, pp531864,2012.

[7] S.A. Burgess, S.H. Flint, and D. Lindsay, Characterization of thermophilic Bacilli from milk powder processing plant. J. Appl. Microbiol. Vol.116:3, pp.50-359, 2013.

[8] M. J.Watterson, D. J. Kent, K. J.Boor, M.Wiedmann , and N. H. Martin , Evaluation of dairy powder products implicates thermophilic sporeformers as the primary organisms of interest. J. Dairy Sci.Vol. 97: 24, pp.87-2497,2014.

[9] S.H.Flint, L.J.H. Ward, and K.M.R. Walker, (b): Functional grouping of thermophilic Bacillus strains using amplification profiles of the 16S$23 \mathrm{~S}$ internal spacer region. Systematic and Appl Microbiol Vol.24, pp.539-548, 2001

[10]R.S.Ronimus L.E. N.Parker, Turner, S.Poudel, A.Ruckert, and , H.W.Morgan ARAPD-based 
comparison of thermophilic bacilli from milk powder. Int. J.MicrobiolVol. 85,pp.45-61, 2003

[11] P.Schelderman, A. Pil, L.Herman, P.De Vos, and M.Heyndrickx, Incidence and diversity of potentially highly heat-resistant spores isolated at dairy farms. Appl and Environ Microbiol Vol.71, pp.1480-1494,2005.

[12] R. D.Ralyea, M.Wiedmann, and K. J.Boor, Bacterial tracking in a dairy production system using phenotypic and ribotyping methods. J. Food Prot.Vol. 61,pp.1336- 1340,1998

[13] J. Hinrichs, and Z.Atamer, Heat treatment of milk sterilization of milk and other products. Reference Module in Food Science Encyclopedia of Dairy Sciences (2nd Ed 714724). 2011

[14]M. C.Te Giffel, A .s .Wagendorp, A.Herrewegh, And F. Driehuis, Bacterial Spores In Silage And Raw Milk, Antonie Van Leeuwen hoek.,Vol.81(1-4), pp.625-30, 2002.

[15] J.Daelman, A.Vermeulen, T.Willemyns, R.Ongenaert, L. Jacxsens, and M.Uyttendaele, Growth/no growth models for heat-treated psychrotrophic Bacillus cereus spores under cold storage. Int. J.Food Microbiol,Vol. 161, pp.7-15, 2013.

[16] D.Gleeson, A.O'Connell, and K. Jordan, Review of potential sources and control of thermoduric bacteria in bulk-tank milk. Irish J. Agricul and Food Research Vol.52, pp. 217227, 2013

[17]A.P.H.A "American Public Health Association" Compendium of methods for microbiological examination of foods. $17 \mathrm{th}$. ed. APHA, Washington D. C. USA.2004.

[18] Oxoid, culture media, ingredients and other laboratory services.8th edition. Published by OXOID LTD. London. Website http://www.oxoid.com 2010.

[19]K T. Kriegy , and L G. Holt, Bergey's Manual of systematic bacteriology. Vol 2, Williams And Wilkins, Baltimore, London.1986

[20]BAM "Bacteriological and Analytical Manual on line" (1998): U.S. Food and Drug Administration. Center for Food Safty and Applied Nutrition

[21] J. R.Huck, , M. Sonnen , and K. J. Boor, Tracking heat-resistant, cold-thriving fluid milk spoilage bacteria from farm to packaged product. J. Dairy Sci. Vol.91, pp.1218-1228, 2008.

[22] H. I. Fromm, and K. J. Boor, Characterization of pasteurized fluid milk shelf-life attributes. J. Food Sci. Vol .69,pp.207-214,2004.
[23] M. Z.Durak, H. I.Fromm, J. R.Huck, R. N. Zadoks and J. Boor,K. Development of molecular typing methods for Bacillus species . and Paeni Bacillus species isolated from fluid milk products. J. Food Sci. Vol.71,pp. 50$56,2006$.

[24] A.M.Aly, Studies on aerobic spore formers in raw and heat treated milk.M.V.SC Thesis, Fac.of Vet Med Cairo Univ.Giza,Egypt.1992.

[25]Lopamudra, and R.K. Kuila, Incidence of different types of spore forming bacteria in pasteurized market milk supplies, Department of Dairy Bacteriol Vol.24 (1) , pp. 20 23,2005.

[26]G.Lotfi , and M.Boumediene, Aerobic spore forming bacteria in the Ultra High Temperature Milk produced in the North West of Algeria Department of Biol, (LAMAABE), J. Agricul. Sci. and Technol A Vol.3, pp.697-702,2013.

[27] M. L. Ranieri, and , K. J. Boor Short communication, Bacterial ecology of high temperature, short-time pasteurized milk processed in the United States. J. Dairy Sci.Vol.92, pp.4833-4840,2009.

[28]M.Heyndrickx, and P. Scheldeman, Bacilli associated with spoilage in dairy and other food products. In: Berkeley, R., Heyndrickx, M., Logan, N., De Vos, P. (Eds.), Applications and Systematics of Bacillus and Relatives. Blackwell Science, Oxford, pp. 64-82.2002

[29]H.Burton, Ultra-High-Temperature Processing of Milk and Milk Products, New York, Elsevier Science Publishing Co., Inc. 1988

[30] M.J. Lewis, microbiological issues associated with heat treated milk .Int.J. of Dairy tech .Vol .(52 ) 4, pp.121-125,1999

[31]A.Gilmour, and M.T. Rowe, Micro-organisms associated with milk In Robinson, R.K. (Ed.), Dairy Microbiol. Elsevier Appl. Sci., London, pp. 37-76,1990.

[32]B.Dogan, and K. J. Boor, Genetic diversity and spoilage potentials among Pseudomonas spp. isolated from fluid milk products and dairy processing plants. Appl. Environ. Microbiol. Vol.69, pp.130-138,2003

[33]J.W. Austin, and G. Bergeron, Development of bacterial biofilms in dairy processing lines. J. Dairy Res.,Vol. 62, pp. 509-519,1995.

[34] C. Faille, F.Fontaine, and Z.Benezech, Potential occurrence of adhering living Bacillus spores in milk products processing lines $\mathrm{J}$. Appl. Microbiol. Vol.90 (6), pp.892-900,2001.

[35]S.Parkar, S. Flint, J.Palmer, and J.Brooks, Factors influencing attachment of thermophilic bacilli to stainless steel. J. Appl. Microbial.Vol. 90,pp.901-908, 2001. 